\title{
9
}

Paulina Kwiatkowska

Uniwersytet Łódzki

http://dx.doi.org/10.18778/8088-905-7.10

\section{Artcoaching jako nowoczesna forma wspierania artystów}

\section{Nowe zawody}

Współczesna gospodarka jest pełna niepewności, a nieznana przyszłość wymaga permanentnej elastyczności i otwartości na zmiany. Nowoczesne technologie, globalizacja, wzrost średniej długości życia (a co za tym idzie - przedłużenie wieku produkcyjnego) niosą za sobą wiele zagrożeń, powodując m.in. spadek popytu na zawody, które do niedawna charakteryzowały się wysokim poziomem stabilizacji (np. rolnictwo, rzemiosło). Stwarza to perspektywy rozwoju i możliwość powstawania nowych profesji. W ekspertyzie Rządowego Centrum Studiów Strategicznych, obejmującej lata 2001-2010, wskazano 9 obszarów tworzenia nowych zawodów i zaproponowano nową klasyfikację zawodów przyszłości (Nowe Zawody 2001: 20-33). W tab. 9.1 uwzględniono część proponowanych zawodów w każdym z obszarów.

Z prognoz przeprowadzonych na początku XXI w. wynikało, że co czwarty lub co piąty Polak w latach 2001-2010 podjął pracę $\mathrm{w}$ zawodzie, będącym $\mathrm{w}$ fazie formowania się. Natomiast 
Tabela 9.1. Nowe zawody

\begin{tabular}{|l|l|}
\hline \multicolumn{1}{|c|}{ Obszar } & \multicolumn{1}{|c|}{ Nowe zawody } \\
\hline $\begin{array}{l}\text { Informatyka, telekomuni- } \\
\text { kacja, internet i technolo- } \\
\text { gie informacyjne }\end{array}$ & $\begin{array}{l}\text { menedżer rozwoju aplikacji } \\
\text { projektant stron www } \\
\text { menedżer systemów wysokiej techniki } \\
\text { specjalista sieci danych } \\
\text { analityk informacji } \\
\text { specjalista - analityk programista }\end{array}$ \\
\hline $\begin{array}{l}\text { Biotechnologia i jej zasto- } \\
\text { sowania }\end{array}$ & $\begin{array}{l}\text { bioinżynier genetyczny } \\
\text { inżynier bioprocesowy } \\
\text { biotechnolog farmaceutyczny }\end{array}$ \\
\hline Ochrona środowiska & $\begin{array}{l}\text { strażnik ochrony przyrody } \\
\text { edukator ekologiczny } \\
\text { architekt ochrony środowiska } \\
\text { pielęgniarz drzew (treeworker) }\end{array}$ \\
\hline $\begin{array}{l}\text { Eksploatacja morza i dnia } \\
\text { morskiego }\end{array}$ & $\begin{array}{l}\text { nurek głębinowy } \\
\text { technolog zasobów morza }\end{array}$ \\
\hline $\begin{array}{l}\text { Obsługa procesów inte- } \\
\text { gracji regionalnej }\end{array}$ & $\begin{array}{l}\text { specjalista ds. administracji międzynarodowej } \\
\text { oficer unijny }\end{array}$ \\
\hline $\begin{array}{l}\text { Nowoczesne operacje fi- } \\
\text { nansowe oraz elektronicz- } \\
\text { na bankowośc i handel } \\
\text { elektroniczny }\end{array}$ & $\begin{array}{l}\text { pracownik scentralizowanych systemów rozli- } \\
\text { czeniowych } \\
\text { projektant pakietów usług finansowych } \\
\text { specjalista od telebankingu } \\
\text { taksator nieruchomości }\end{array}$ \\
\hline $\begin{array}{l}\text { Ochrona zdrowia i opieka } \\
\text { społeczna }\end{array}$ & $\begin{array}{l}\text { inżynier kliniczny } \\
\text { inspektor farmaceutyczny } \\
\text { terapeuta oddechowy }\end{array}$ \\
\hline $\begin{array}{l}\text { Informacja kultury popu- } \\
\text { kowego przemysłu rozryw- }\end{array}$ & $\begin{array}{l}\text { edytor filmu i wideo } \\
\text { archiwista dokumentów elektronicznych } \\
\text { broker informacji } \\
\text { specjalista ds. kultury firm } \\
\text { animator parków rozrywki }\end{array}$ \\
\hline Edukacja & $\begin{array}{l}\text { teletutor } \\
\text { broker dydaktyczny } \\
\text { trener/szkoleniowiec } \\
\text { menedżer programów szkoleniowych }\end{array}$ \\
\hline arno
\end{tabular}

Źródło: opracowanie własne na podstawie: Nowe Zawody (2001) 
na podstawie projektu przygotowanego przez Komitet Prognoz „Polska 2000 plus” można wnioskować, że do 2025 r. udział nowych zawodów oraz specjalności będzie się zwiększał i może osiągnąć poziom 40-50\% powstających nowych miejsc pracy (Podlaskie Obserwatorium, 2012: 27). Wzrost liczby nowych zawodów i specjalności jest wyraźnie widoczny. Takie profesje jak tester gier, fundraiser czy trendsetter nie istniały jeszcze 10 lat temu. Aktualnie, według danych Work Service SA, te zawody cieszą się dużą popularnością i wysokim wynagrodzeniem. W tab. 9.2 uwzględniono wynagrodzenia nowo powstałych zawodów (www.workservice.pl).

Tabela 9.2. Wynagrodzenia w nowych zawodach

\begin{tabular}{|l|c|c|}
\hline \multicolumn{1}{|c|}{ Nowe zawody } & $\begin{array}{c}\text { Wynagrodzenie } \\
\text { brutto (w PLN) }\end{array}$ & $\begin{array}{c}\text { Średnie } \\
\text { wynagrodzenie } \\
\text { brutto (w PLN) }\end{array}$ \\
\hline Programista & $9500-14000$ & 11750 \\
\hline Coach biznesowy & $5800-10400$ & 8100 \\
\hline Manager Social Media & $4900-9600$ & 7250 \\
\hline Employer Branding Manager & $4200-6200$ & 5200 \\
\hline Analityk Compliance & $3200-6700$ & 4900 \\
\hline Fundraiser & $2900-5800$ & 4350 \\
\hline Tester gier/aplikacji & $3300-4900$ & 3900 \\
\hline Trendsetter & $2600-5200$ & 400 \\
\hline
\end{tabular}

Źródło: Work Service SA

Wśród wymienionych zawodów znalazł się coach biznesowy - specjalizacja, która dynamicznie się rozwija. Business coaching, czyli proces przeznaczony dla osób pracujących i polegający na wsparciu coacha w kwestiach związanych z zawodem klienta (www.internationalcoachingcommunity.com to tylko jedna $z$ wielu specjalizacji coachingu, jeszcze do niedawana nieznanego prawie nikomu w Polsce. 


\section{Czym jest coaching?}

Dziedzina ta jest coraz częściej badana i opisywana, głównie w psychologii i naukach o zarządzaniu ${ }^{1}$. Doczekała się wielu definicji, które, uogólniając, określają coaching jako proces oparty na relacji partnerskiej. Wynikiem tego procesu jest wywołanie pozytywnej zmiany w życiu zawodowym lub prywatnym klienta. Coaching odróżnia się od dziedzin takich jak terapia, trenerstwo czy mentoring ${ }^{2}$ (Clutterbuck 2009: 16-25).

Rozwój tej profesji w naszym kraju zaczął się wraz z przyjazdem Josepha O'Connora i Andrei Lages-O'Connor do Lublina w 2002 r. Para znanych coachów i trenerów NLP (Programowania Neurolingwistycznego) przeprowadziła wówczas pierwszy $\mathrm{w}$ Polsce kurs coachingu, International Coaching Certification. Dzięki temu w kraju pojawili się pierwsi coachowie i można było proponować usługę na poziomie profesjonalnym. Od tamtej pory polscy reprezentanci tej dziedziny zaczęli prowadzić kursy i szkolenia certyfikacyjne, powstały także polskie szkoły, mające coaching w ofercie edukacyjnej (Pilipczuk, 2012: 9-10).

\section{Coach jako zawód}

Od 2014 r. profesja coacha doczekała się wpisu do Krajowej Klasyfikacji Zawodów i Specjalności. Widnieje pod nazwą trener osobisty (coach, mentor, tutor) i określona jest jako

${ }^{1}$ Badaniami w zakresie coachingu w organizacji zajmują się m.in. Blanchart, Johnson, Holliday, O’Neil, Czarkowska, Huflejt-Łukasik, Smółka.

${ }_{2}^{2}$ Terapia skupia się na konkretnych problemach, takich jak trauma, choroba psychiczna, podczas gdy coaching wspiera klienta w ogólnych sytuacjach życiowych, poprawia wyniki i pomaga w osiaganiu celów. Terapeuta w pracy skupia się na przeszłości - coach na teraźniejszości i przyszłości. Mentoring jest prowadzeniem klienta. Mentor, w odróżnieniu od coacha, jest ekspertem w dziedzinie klienta, udziela rad i wskazówek. Trenerstwo to rodzaj szkolenia, podczas którego trener przekazuje informacje, czerpiąc z różnych źródeł, w coachingu zaś klient poszerza wiedzę, którą już posiada. Coach, w przeciwieństwie do trenera, wykorzystuje jedynie potencjał klienta, nie przekazuje konkretnej wiedzy z zakresu szkolenia, warsztatu. 
osoba, która „pomaga klientowi dokonywać zmiany w rozwoju osobistym i zawodowym oraz realizacji wyznaczonych celów; wspiera proces zmiany we wszystkich obszarach życia: odkrywa niewykorzystany potencjał człowieka w sesjach indywidualnych i zbiorowych; wzbudza motywację do działania; wspólnie z klientem znajduje skuteczne rozwiązania" (www.psz.praca.gov.pl).

Współczesny rynek oferuje wiele kursów i certyfikacji. Do najbardziej popularnych instytucji wydających certyfikat coacha w Polsce należą Izba Coachingu, International Coach Federation, European Mentoring and Coaching Counsil Poland. Ponadto $\mathrm{w}$ internecie można znaleźć kilkadziesiąt ofert firm i szkół kształcących coachów. Mnogość ofert powoduje, że trudno jest określić dokładną liczbę osób wykonujących ten zawód w naszym kraju. Firma HPR Group szacuje, że obecnie na rynku polskim działa około 10000 coachów, ale tylko część z nich posiada udokumentowaną wiedzę i kompetencje (www.swiatcoachingu.pl).

Wzrost liczby coachów powoduje zawężanie specjalizacji i tworzenie nowych zawodów. W Encyklopedii coachingu wyróżnia się m.in. wspomniany wcześniej biznes coaching, ale również executive coaching, team coaching, career coaching, life coaching (www.encyklopediacoachingu.pl). W internecie dostępne są również oferty dietcoachingu, artcoachingu, zencoachingu, sexcoachingu, somatic coacingu, VIPcoachingu, czy homecoachingu. Świadczy to o zapotrzebowaniu na rynku i modzie na te dyscypliny.

\section{Czym jest artcoaching?}

Jednym z rodzajów coachingu jest artcoaching. Profesja artcoacha dopiero się rozwija, dlatego w literaturze trudno jest znaleźć jej dokładny opis i naukową definicję. Najogólniej mówiąc, artcoaching jest to proces polegający na współpracy profesjonalnego coacha i artysty, podczas którego coach ma za zadanie 
wspierać twórcę w realizowaniu celów. Herbert Fitzek definiuje artcoaching jako gałąź teorii Gestalt ${ }^{3}$ w sztuce i kulturze, posługującą się odbiorem sztuki jako narzędziem do intensyfikacji indywidualnych i grupowych zmian (Fitzek, 2013: 42-43). Według Małgorzaty Marczewskiej (coacha ICC, certyfikowanej m.in. przez Josepha O'Connora, propagatorki artcoachingu w Polsce), jest to rodzaj coachingu zajmujący się pracą z artystą. Polega na wspieraniu twórców w odkrywaniu i uruchamianiu ich potencjału oraz w wyznaczaniu i osiąganiu celów na podstawie ich zasobów (www.scenariopisarstwo.pl). Marczewska, jako pierwsza w Polsce, w 2014 r. przeprowadziła autorski, otwarty, roczny certyfikowany kurs artcoachingu, przygotowując do profesji kilkanaście osób i dając uprawnienia 7 artcoachom. Certyfikat artcoacha proponuje również w swojej ofercie Maciej Bennewicz (www.normanbenett.pl). Zaznaczyć należy, że - podobnie jak w przypadku klasycznego coachingu - brakuje informacji, ilu certyfikowanych i nieposiadających uprawnień artcoachów wykonuje tę profesję.

Podsumowując powyższe opisy i zestawiając je z naukowymi definicjami coachingu oraz opisem profesji coacha w Krajowej Klasyfikacji Zawodów i Specjalności, stwierdzić można, że artcoach jest profesjonalistą wspierającym twórców w realizacji celów artystycznych, zawodowych i prywatnych. Podczas procesu artysta pokonuje drogę od zrealizowania do osiagania celów, zaś artcoach, za pomocą umiejętnie dobranych technik i metod, wspiera artystę w drodze do sukcesu. Artcoach, stosując klasyczne i kreatywne metody i wykorzystując sztukę, pobudza potencjał artysty i motywuje twórcę do podjęcia działań, przybliżających do realizacji wyznaczonych celów. Efektem artcoachingu jest wywołanie pozytywnej zmiany w różnych obszarach życia artysty.

Odróżniając artcoaching od klasycznego coachingu, należy wskazać różnicę dotyczącą grupy docelowej i metod współpra-

${ }^{3}$ Gestalt - forma psychoterapii i kierunek w psychologii, głoszący holistyczne podejście do percepcji. Podstawowe przesłanie teorii Gestalt zawiera się w zdaniu: "Całość to coś innego niż suma jej elementów”. 
cy. Odbiorcami artcoachingu są twórcy i osoby kreatywne, aspirujące do wykonywania zawodu artysty, a obok klasycznych i kreatywnych metod wykorzystuje się sztukę i proces tworzenia. Zawężając specjalizację do pracy z twórcami, warto zastanowić się, dlaczego artcoaching jest potrzebny i może stać się zawodem przyszłości.

\section{Przykłady zastosowań artcoachingu}

Nie ulega wątpliwości, że artcoach jest nowym i dopiero tworzącym się zawodem. Nasuwa się zatem pytanie, co powoduje, że jest to profesja potrzebna we współczesnym świecie? Aby znaleźć odpowiedź, należy określić, co charakteryzuje twórców oraz dlaczego artyści potrzebują coachingu.

Nie od dziś wiadomo, że artystów wyróżnia twórczość, utożsamiana również z kreatywnością. W XIX w. cechę tę przypisywano głównie artystom i jednostkom genialnym (Jerzyk $\mathrm{i}$ in. 2004: 9). Jest ona często opisywana ${ }^{4} \mathrm{w}$ psychologii, socjologii, pedagogice i naukach o zarządzaniu jako myślenie nieschematyczne, wykorzystujące i łączące wiedzę z różnych dziedzin do tworzenia nowych rozwiązań. Edward Nęcka za najbardziej aktualną uznaje definicję Steina, opisującą twórczość jako „proces prowadzący do nowego wytworu, który jest akceptowany jako użyteczny lub do przyjęcia dla pewnej grupy w pewnym okresie" (Nęcka, 2012: 18). Ponieważ efektem pracy artysty jest stworzenie dzieła sztuki, należy uznać, że jest on osobą kreatywną. Nęcka wymienia indywidualne cechy twórców, zaliczając do nich m.in. ponadprzeciętną inteligencję, szczególny styl poznawczy (charakteryzujący się postrzeganiem rzeczywistości niezależnie od narzuconych wzorców), zwiększoną refleksyjność, intuicję oraz skłonność do narzucania własnych norm i reguł (Nęcka, 2012: 129-152).

${ }^{4}$ Badaniami nad twórczością $\mathrm{w}$ wymienionych dziedzinach zajęli się m.in. Taylor, Rhodes, Johnson, Boden, Stein, Dewey, de Bono, Nęcka, Jerzyk i Fazlagić. 
Syntezą cech osób kreatywnych zajął się również Jan Fazlagić, wyróżniając 9 cech osobowościowych (Fazlagić, 2015: 8182). Są to:

1) silna motywacja wewnętrzna;

2) wytrwałość;

3) ciekawość intelektualna;

4) niezależność myślenia;

5) pewność siebie;

6) otwartość na doświadczenia;

7) tolerancja dla wieloznaczności;

8) zdolność myślenia w kategoriach przeciwieństw;

9) zdolność łączenia myślenia logicznego z abstrakcyjnym.

W momencie, kiedy artysta odczuwa kryzys twórczy, spadek kreatywności lub niedostatek którejkolwiek z wymienionych cech, wsparciem może się okazać proces artcoachingowy, którego efektem staje się wywołanie pozytywnej zmiany w różnych obszarach życia twórcy. Warto zatem opisać wskazane cechy (Fazlagić, 2015: 66-82), poszukać zastosowań artcoachingu do ich kształtowania i rozwijania, w czym mogą pomóc literatura przedmiotu i praktyka artcoachingowa.

1. Silna motywacja wewnętrzna. Fazlagić uważa, że twórcy są często wewnątrzsterowni, co oznacza, że czerpią motywację z własnego wnętrza, a nie z otoczenia. Zadaniem artcoachingu jest pobudzanie wewnętrznego potencjału artysty i motywowanie do podjęcia wyznaczonych przez siebie działań. Oznacza to, że opierając się na wewnętrznym potencjale twórcy, artcoaching może wspierać artystów w momencie obniżonej motywacji wewnętrznej. Ponadto, odnosząc się do badań wskazujących różnice $\mathrm{w}$ motywowaniu osób kreatywnych w branży kreatywnej, do motywowania pracowników innych branżach (Andresen, 2009), można wnioskować, że wykorzystanie kreatywnych metod zwiększy motywację twórców.

2. Wytrwałość. Cecha ta została opisana jako „nieuleganie przeszkodom”. Fazlagić uważa, że osoby twórcze nie pozwalają by ból i cierpienie, wynikające z trudności w osiągnięciu celu, przeszkodziły w jego realizacji. Wytrwałość w zawodzie artysty jest bardzo istotna. Praktyka pokazuje, że dzieła sztuki tworzy 
się miesiącami, czasem latami. Artyści często nie kończą rozpoczętych prac. Powodem mogą być czynniki zewnętrzne, niezależne od twórcy, takie jak np. trudne relacje w środowisku artystów czy nieoczekiwany brak środków na dokończenie dzieła. Podczas artcoachingu twórca ma możliwość przełamania impasu, spojrzenia na swoją sytuację z różnych perspektyw oraz znalezienia nowej drogi realizacji swoich celów.

3. Ciekawość intelektualna. Jest to cecha rozumiana przez autora jako pasja związana z odkrywaniem nowych rzeczy. Współczesny system edukacji, w tym szkoły artystyczne, wydając opinie i stosując oceny, mogą ograniczać ciekawość świata przyszłych twórców. Artcoaching, stosując kreatywne metody, wychodzi poza klasyczne ramy myślenia, poszerzając ciekawość intelektualną artystów.

4. Niezależność myślenia. Fazlagić wiąże tę cechę z wygłaszaniem przez twórców poglądów podważających istniejący stan rzeczy. Takie zachowanie odbierane jest często jako agresywne i może powodować niechęć wyrażania swoich opinii lub rozluźnianie relacji międzyludzkich. Powodem bywa niski poziom asertywności twórcy. Techniki stosowane w artcoachingu zakładają kształtowanie i rozwijanie asertywności artysty.

5. Pewność siebie. Jest to śmiałość i odwaga w wyrażaniu swoich opinii. Fazlagić wyróżnił objawy braku pewności, do których zaliczył m.in. brak jasno sprecyzowanego celu, brak umiejętności radzenia sobie z porażkami, poleganie na spontaniczności i brak przygotowania na niepowodzenia czy postrzeganie siebie jako osoby skrzywdzonej przez los. Artcoach już na początku procesu pozwala zdefiniować problem oraz sprecyzować konkretne cele, które twórca pragnie zrealizować. Następnie wspiera w przygotowaniu planu działania, uwzględniając możliwość występowania ewentualnych porażek i określając tzw. „plan B”. Artcoach towarzyszy twórcy w drodze do realizacji celów, co oznacza, że wspiera go w momentach niepowodzeń i sukcesów. Forma procesu daje możliwość kontaktu $\mathrm{z}$ artcoachem poza sesjami, co znacznie ułatwia wzmacnianie pewności siebie artysty. 
6. Otwarcie na doświadczenia. Cecha ta wiąże się z gotowością do zmian, co może oznaczać, że twórca chętniej zdecyduje się na proces artcoachingowy niż osoba, która na doświadczenia jest zamknięta. Warto zaznaczyć, że artcoaching nie jest metodą uniwersalną i nie każdy twórca powinien $z$ tej formy wsparcia skorzystać. Artcoaching jest procesem wymagającym zaangażowania artcoacha i artysty. Gdy jedna ze stron nie wykazuje zaangażowania, proces nie przynosi oczekiwanych rezultatów. W takiej sytuacji nie należy go rozpoczynać, trzeba go przerwać, co określają warunki kontraktu artcoachingowego ustalonego podczas sesji wstępnej.

7. Tolerancja dla wieloznaczności. Autor określa tę cechę jako tolerowanie złożoności. Twórcy odbierają rzeczywistość wielopoziomowo, określając różne zjawiska jednocześnie jako dobre i jako złe. Wyzbywają się w ten sposób jednoznacznych ocen. Jedną z zasad artcoacha jest całkowite odrzucenie ocen. Ułatwia to wykonywanie pracy $\mathrm{z}$ pominięciem rad i sugestii, które są charakterystyczne m.in. w mentoringu i w doradztwie. Dzięki temu artysta sam generuje rozwiązania i podejmuje decyzje w pełni zgodne z własnym systemem wartości.

8. Zdolność do myślenia w kategoriach przeciwieństw. Fazlagić przytacza tu przykład filmu o żabie. Twierdzi, że twórca podczas oglądania filmu o największej żabie świata natychmiast myśli o tym, jak wygląda żaba najmniejsza na świecie. Artcoaching prowokuje do myślenia przeciwstawnego, otwierając twórcy nowe perspektywy.

9. Zdolność łączenia. Jest to umiejętność łączania myślenia logicznego z abstrakcyjnym. Proces artcoachingowy wspiera zarówno myślenie logiczne, doprecyzowując i konkretyzując myśli twórcy, jak i myślenie abstrakcyjnie, stosując m.in. kreatywne metody rozwiązywania problemów. Ponadto techniki używane w artcoachingu koordynują pracę lewej i prawej półkuli mózgu, co wzmacnia zdolność łączenia myślenia logicznego z abstrakcyjnym.

W celu jak najdokładniejszego zobrazowania zastosowań artcoachingu w rozwijaniu wymienionych cech opracowano grafy, uwzględniające nazwę cechy, przykład sytuacji problemo- 
wej, podczas której artysta odczuwa spadek wymienionej cechy oraz nazwy proponowanych narzędzi wykorzystywanych w coachingu (Marciniak, Rogala-Marciniak, 2013) i artcoachingu ${ }^{5}$.

Zastosowania przedstawiono zgodnie $\mathrm{z}$ przedstawionym schematem.

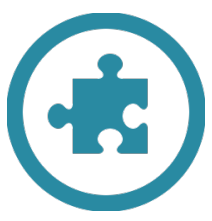

CECHA

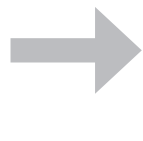

SYTUACJA PROBLEMOWA

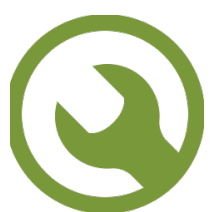

PRZYKŁAD NARZĘDZIA ARTCOACHINGOWEGO

Należy zaznaczyć, że wymienione narzędzia obrazują jedynie przykładowe zastosowanie. Można ich używać zamiennie w zależności od sytuacji problemowej twórcy i łączyć z technikami kreatywnymi oraz narzędziami sztuki (rys. 9.1). Warto także dodać, że omówione narzędzia można także stosować w innych sytuacjach, niezwiązanych z rozwijaniem wymienionych cech.

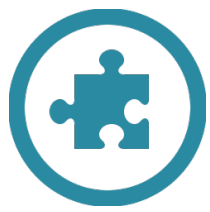

SILNA

MOTYWACJA WEWNĘTRZNA
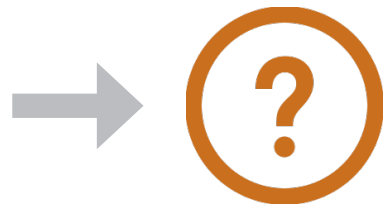

TWÓRCA NIE POSIADA MOTYWACJI DO WYKONYWANIA REGULARNYCH CZYNNOŚCI ZMIERZAJĄCYCH DO ROZPOCZĘCIA WŁASNEJ DZIAŁALNOŚCI

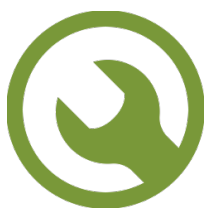

DIAGRAM AUTOANALIZY KARTY MOTYWACJI KOŚCI HISTORII

5 Techniki artcoachingowe wykorzystują techniki coachingowe, techniki kreatywne i sztukę. Należy zatem pamiętać, że wymienione techniki mogą być modyfikowane w zależności od klienta oraz problemu i stosowane w formie kreatywnej lub z wykorzystaniem sztuki. 


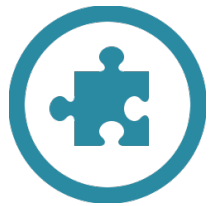

WYTRWAŁOŚĆ
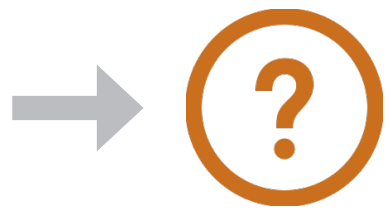

TWÓRCA CHCE PRZERWAĆ PROJEKT Z POWODU ODEJŚCIA KILKU WSPÓŁPRACOWNIKÓW
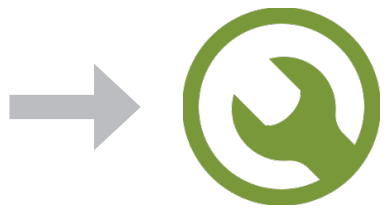

LISTY GDYBANIA METODA WALTA DISNEYA ŁUK ZMIANY

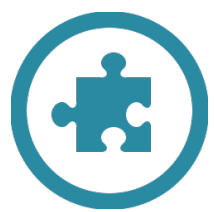

CIEKAWOŚĆ INTELEKTUALNA
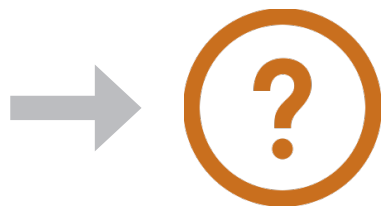

TWÓRCA NIE INTERESUJE SIĘ ZJAWISKAMI SPOZA OTOCZENIA ARTYSTYCZNEGO

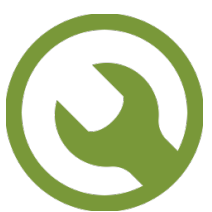

MAPA SYTUACYJNA

LISTY GDYBANIA KOLAŻ "JA I OTOCZENIE"

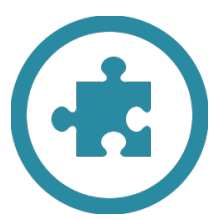

NIEZALEŻNOŚĆ MYŚLENIA

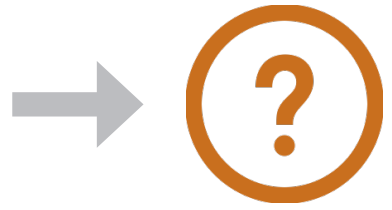

TWÓRCA, W WYGŁASZANIU POGLĄDÓW, KIERUJE SIĘ OPINIĄ OTOCZENIA

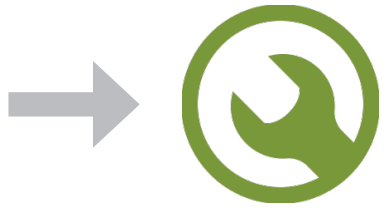

KARTY MOTYWACJI KOŚCI HISTORII PIRAMIDA POZIOMÓW LOGICZNYCH

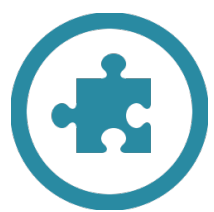

PEWNOŚĆ SIEBIE

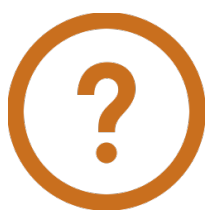

TWÓRCA NIE WIERZY W POWODZENIE SWOICH DZIAŁAŃ

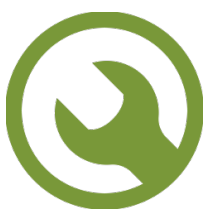

LISTY GDYBANIA DIAGRAM AUTOANALIZY WIZUALIZACJA 


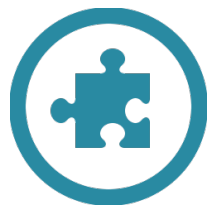

OTWARCIE

NA DOŚWIADCZENIA

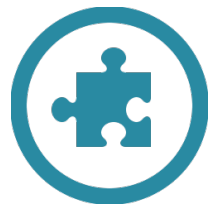

TOLERANCJA DLA WIELOZNACZNOŚCI

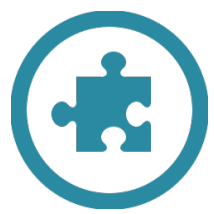

ZDOLNOŚĆ DO MYŚLENIA W KATEGORIACH PRZECIWIEŃSTW

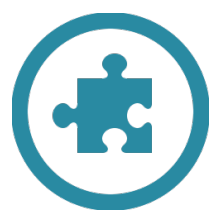

ZDOLNOŚĆ ŁĄCZENIA
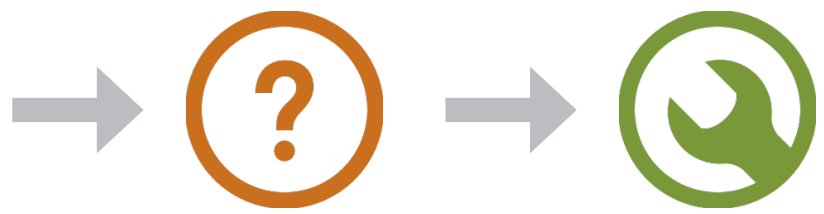

TWÓRCA WIDZI TYLKO JEDNĄ DROGĘ REALIZACJI CELU

ŁUK ZMIANY

WIZUALIZACJA METODA WALTA DISNEYA

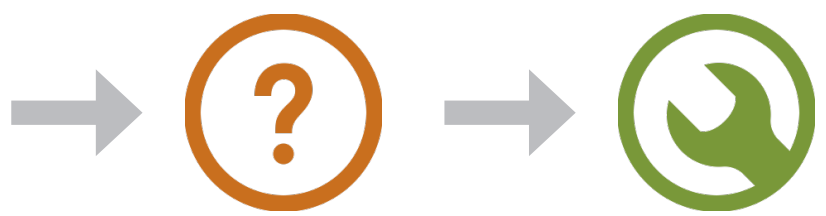

TWÓRCA JEDNOSTRONNIE

WACHLARZ KONCEPCJI OCENIA RZECZYWISTOŚĆ

RÓWNOWAGA JIN-JANG MODEL CARE
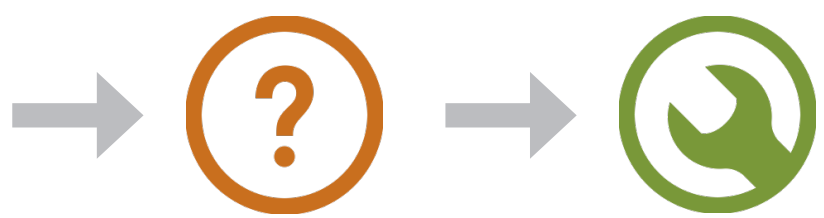

TWÓRCA ROZPTARUJE PROBLEM

WACHLARZ KONCEPCJI TYLKO ZE SWOJEJ PERSPEKTYWY METODA WALTA DISNEYA RÓWNOWAGA JIN-JANG
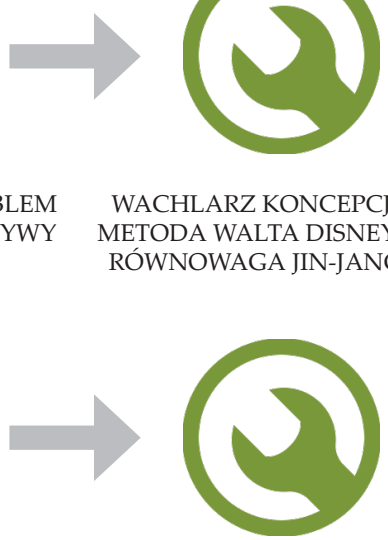

TWÓRCA KONSTRUUJE ABSTRAKCYJNE CELE

METODA SMART METODA GOAL INDYWIDUALNY PLAN ROZWOJU

Rysunek 9.1. Zastosowanie narzędzi artcoachingu w rozwijaniu cech osobowościowych artysty

Źródło: opracowanie własne 


\section{Podsumowanie}

Artcoaching jest jedną z tworzących się profesji. Zasadne jest nazwanie artcoachingu zawodem przyszłości, ponieważ jest to nowoczesna i potrzebna forma wsparcia artystów pracujących zarówno w branży kreatywnej, jak i uprawiających wolne zawody. Jest to specjalizacja intensywnie rozwijającego się w ostatnich latach coachingu, który niedawno doczekał się wpisu do Krajowej Klasyfikacji Zawodów i Specjalności. Artcoaching jest na tyle młody, że brakuje jego opisu w literaturze. Sprecyzowana powyżej definicja oraz propozycje zastosowania są w dużej mierze opisem doświadczeń autorki i obserwacji wynikających z praktyki wykonywania profesji, wymagających potwierdzenia w postaci badań naukowych. Twórcy potrzebują wsparcia, zarówno w życiu zawodowym, jak i prywatnym, a jedną z metod stanowi zaproponowany artcoaching. Forma ta różni się od klasycznego coachingu ze względu na grupę docelową i niektóre metody. Artystów odróżniają od innych pracowników konkretne cechy osobowościowe, co może oznaczać, że potrzebują odmiennego wsparcia niż osoby pracujące w branżach niekreatywnych. Warto zatem ustalić, jakie kompetencje powinien posiadać artcoach i czym różnią się one od kompetencji klasycznego coacha. Jest to kolejna luka zauważalna w nauce, która z pewnością wkrótce doczeka się wyjaśnienia i opisania.

\section{Literatura}

Andresen T. F. (2009), Motivating Creative Employees in Creative Businesses, Cand. Soc. CBP.

Clutterbuck D. (2009), Coaching zespołowy, Rebis, Poznań.

Fazlagić J. (2015), Kreatywni w biznesie, Poltex, Warszawa.

Fitzek H. (2013), Artcoaching. Gestalt theory in Arts and Culture, "Gestalt Theory", Vol. 35, No. 1.

Jerzyk E., Leszczyński G., Mruk H. (2004), Kreatywność w biznesie, Wydawnictwo Akademii Ekonomicznej w Poznaniu, Poznań.

Marciniak Ł.T., Rogala-Marciniak S. (2013), Coaching. Zbiór narzędzi wspierania rozwoju, Wolters Kluwer SA, Warszawa. 
Nęcka E. (2012), Psychologia twórczości, Gdańska Wydawnictwo Psychologiczne, Sopot.

Nowe Zawody (2001), Nowe Zawody oraz elastyczne formy zatrudnienia, „Studia i Materiały", t. 6, Rządowe Centrum Studiów Strategicznych, Warszawa.

Pilipczuk P. (2012), Wspótczesna mitologia coachingu. 70 konkretnych odpowiedzi na 70 zasadniczych pytań, Wydawnictwo Helion, Gliwice.

Zawody Przyszłości (2012), Zawody Przyszłości - Raport I, Podlaskie Obserwatorium Rynku Pracy i Prognoz Gospodarczych, Wojewódzki Urząd Pracy w Białymstoku, Białystok.

\section{Strony internetowe}

http://encyklopediacoachingu.pl/haslo59 [dostęp: 23.05.2016].

http://www.internationalcoachingcommunity.com/en/faq-what-are-the-different-types-of-coaching [dostęp: 23.05.2016].

http://normanbenett.pl/portfolio/art-coaching/ [dostęp: 23.05.2016].

http://www.scenariopisarstwo.pl/podkast-malgorzata-marczewska-art-coaching/ [dostęp: 23.05.2016].

http://swiatcoachingu.pl/biznesowo/442-rynek-coachingowy-w-polsce [dostęp: 23.05.2016].

http://psz.praca.gov.pl/rynek-pracy/bazy-danych/klasyfikacja-zawodow-i-specjalnosci/wyszukiwarka-opisow-zawodow/ [dostęp: 23.05.2016].

http://www.workservice.pl/Centrum-prasowe/Informacje-prasowe/Ekspert-HR-komentuje/Nowe-zawody-kusza-wysokimi-wynagrodzeniami [dostęp: 23.05.2016]. 